\title{
MOLECULAR DIAGNOSIS OF CASEOUS LYMPHADENITIS IN SHEEP AT DAKAHLIA GOVERNORATE, EGYPT
}

\author{
*Selim.A.m, *Atwa.S.M, **EI-Gedawy .A.A and *Younis .E.A \\ * Internal medicine, Infectious and Fish diseases Department, Faculty of Veterinary Medicine, Mansoura University \\ **Bacteriology Department ,Animal Health Research Institute ,Dokki, Giza
}

\begin{abstract}
The aim of the present study was to diagnose caseous lymphadenitis in sheep by PCR assay. A total of 1257 sheep from different flocks in Dakahlia governorate were clinically examined during the period of January 2014 to February 2015. sheep were classified according to the status of infection in the flocks to infected, incontact and free ones. 37 needle biopsy samples were randomly collected from 26 diseased, 7 incontact and 4 free examined sheep for PCR assay. rpoB gene was detected in 37 samples (100\%) while PLD gene was in 18 samples (48.64\%), from which 16 from diseased sheep and two from incontact ones, while not detected in free sheep. The PCR assay was rapid, specific and significant technique as bacterial culture in detecting corynbacterium pseudotuberculosis in needle biopsy samples from sheep.
\end{abstract}

Keywords: Caseous lymphadenitis. Corynebacterium pseudotuberculosis . Sheep Polymerase chain reaction. Lymph nodes biopsy.

\section{INTRODUCTION}

Caseous Lymphadenitis (CLA) is a chronic, contagious, transmissible disease of sheep and goat caused by Corynebacterium pseudotuberculosis (Droppa-Almeida et al., 2016; Oreiby, 2015). CLA causes severe economic losses of animal industry all over the world (Williamson, 2001).

The disease is characterized by chronicity and in many cases appears in subclinical form in small ruminants across the world (Dorella et al., 2006). CLA is manifested clinically by large swellings of superficially located lymph nodes that contains infectious agent, which may be discharged through ruptured abscesses (O'Reilly et al., 2006). Mature lesions are characterize by concentric lamellations which located in the center of the lesion. These lesions usually are seen in the external lymph nodes, lungs and, less commonly in other organs (Severini et al., 2003).

Polymerase chain reaction (PCR) is a promising method, which used for detection of corynebacterium pseudotuberculosis in bacterial colonies or in pus samples (Çetinkaya et al., 2002; Pacheco et al., 2007). The obstacles facing PCR to detect caseous lymphadenitis cases are inability to take samples from visceral lesions and the questionable results of PCR when performed on blood samples.PCR significantly improves rapid detection of C.Pseudotuberculosis and could supersede bacteriological culture for microbiological and epidemilogical diagnosis 
of CLA (Pacheco et al., 2007). As microbiological and biochemical methods are not always straightforward, the development of a rapid and specific diagnostic tool is imperative for the diagnosis of CLA (Çetinkaya et al., 2002), therefore we used PCR .

This study aimed to detect $C$. Pseudotuberculosis in needle biopsy samples by PCR .

\section{MATERIAL \&METHODS}

\section{1-Animals:}

A total of 1257 sheep from 34 different flocks in Dakahlia Governorate were clinically examined during the period of January 2014 to February 2015. Sheep were classified according to the status of infection of flock into infected, incontact and free (Radostitis et al., 2007).

\section{2-Needle biopsy samples :}

A total of 37 needle biopsy samples obtained under complete aseptic condition from superficial lymph nodes were obtained for DNA extraction and PCR assay (infected, $\mathrm{n}=$ 26; normal, $n=11$ ). Fine needle biopsy (FNB) is a procedure in which a small -caliber single use needle is placed into mass ( lymph node tissue ) and cellular material is removed (Zajdela et al., 1987) .Tissue taken by needle was placed in sterile epindorf containing PBS and sent to lab in ice box and kept at $-20^{\circ} \mathrm{C}$ until processed for PCR diagnosis .

\section{3-Polymerase chain reaction (PCR):}

PCR was performed in the Biotechnology Laboratory of Animal Health Research Institute, El-Dokki, Egypt. It was applied to detect $C$. pseudotuberculosis in needle biopsy samples based on two specific genes (rpoB and PLD), according to (Sammra et al., 2014) and (Ilhan, 2013), respectively.

\subsection{DNA extraction for PCR :}

QIAamp DNA Mini Kit ( Catalogue no.51304 ). Using.

\subsection{Oligonucleotide primers used in $\mathbf{C P C R}$}

They have specific sequence and amplify a specific product as shown in Table (1).

\section{RESULTS}

\section{Clinical findings I-}

Applied on 1257 sheep . 37 sheep were randomly selected, from which 26 clinically diseased , 11 incontact and 4 free sheep.The clinical signs appeared on diseased sheep were abscessiation of superficial lymph nodes.Closed abscesses were ranged in size from bean's size up to orange size (Figure 2), where they can be palpated by hand.In opened abscesses the pus color in some cases was creamy (figure 3) and other cases may be greenish.Consistency was varied from fluid to hard caseous materials and lamellations may be noticed and wool over abscesses lost(Figure 1) .Some animals showed signs of internal abcessiation like chronic ill-thrift and poor condition .

\section{Molecular findings: II-}

Out of 37 needle biopsy examined samples for PCR assay, $37(100 \%)$ were positive rpoB indicated at $406 \mathrm{bp}$ (Figures 4 and 5), while $18(48.64 \%)$ were positive PLD results indicated at $203 \mathrm{bp}$ (Figures 6 and 7), from which 16 infected sheep and 2 incontact sheep but not detected in free sheep. 
Table (1) Oligonucleotide primers sequences

Source: Metabion (Germany)

\begin{tabular}{|c|c|c|c|}
\hline Gene & Sequence & $\begin{array}{c}\text { Amplified } \\
\text { product }\end{array}$ & Reference \\
\hline \multirow{2}{*}{ Pld } & ATA AGC GTA AGC AGG GAG CA & \multirow{2}{*}{$203 \mathrm{bp}$} & \multirow{2}{*}{ (Ilhan, 2013) } \\
\hline & ATC AGC GGT GAT TGT CTT CCA GG & & \\
\hline \multirow{2}{*}{ rроB } & CGWATGAACATYGGBCAGGT & \multirow{2}{*}{$406 \mathrm{bp}$} & \multirow{2}{*}{$\begin{array}{c}\text { (Sammra et al. } \\
\text { 2014) }\end{array}$} \\
\hline & TCCATYTCRCCRAARCGCTG & & \\
\hline
\end{tabular}

\subsection{PCR Master Mix used for cPCR}

Table (2): according to Emerald Amp GT PCR mastermix (Takara) Code No. RR310A kit as shown in table (2):

\begin{tabular}{|c|c|}
\hline Component & Volume/reaction \\
\hline Emerald Amp GT PCR mastermix (2x premix) & $12.5 \mu \mathrm{l}$ \\
\hline PCR grade water & $4.5 \mu \mathrm{l}$ \\
\hline Forward primer (20 pmol) & $1 \mu \mathrm{l} \mu \mathrm{l}$ \\
\hline Reverse primer (20 pmol) & $6 \mu \mathrm{l}$ \\
\hline Template DNA & $25 \mu \mathrm{l}$ \\
\hline Total & 125 \\
\hline
\end{tabular}

Table (3): Cycling conditions of the different primers during cPCR

\begin{tabular}{|c|c|c|c|c|c|c|}
\hline Gene & $\begin{array}{c}\text { Primary } \\
\text { denaturation }\end{array}$ & $\begin{array}{c}\text { Secondary } \\
\text { denaturation }\end{array}$ & Annealing & Extension & $\begin{array}{c}\text { No. of } \\
\text { cycles }\end{array}$ & $\begin{array}{c}\text { Final } \\
\text { extension }\end{array}$ \\
\hline \multirow{2}{*}{$P L D$} & $94^{\circ} \mathrm{C}$ & $94^{\circ} \mathrm{C}$ & $56^{\circ} \mathrm{C}$ & $72^{\circ} \mathrm{C}$ & 35 & $72^{\circ} \mathrm{C}$ \\
& $5 \mathrm{~min}$. & $30 \mathrm{sec}$. & $30 \mathrm{sec}$ & $30 \mathrm{sec}$ & 35 min. \\
\hline \multirow{2}{*}{$r p o B$} & $94^{\circ} \mathrm{C}$ & $94^{\circ} \mathrm{C}$ & $52^{\circ} \mathrm{C}$ & $72^{\circ} \mathrm{C}$ & 35 & $72^{\circ} \mathrm{C}$ \\
& $5 \mathrm{~min}$. & $30 \mathrm{sec}$. & $45 \mathrm{sec}$ & $45 \mathrm{sec}$ & & $5 \mathrm{~min}$. \\
\hline
\end{tabular}




\subsection{Agarose gel electrophoreses}

Modified from (Sambrook et al., 1989).
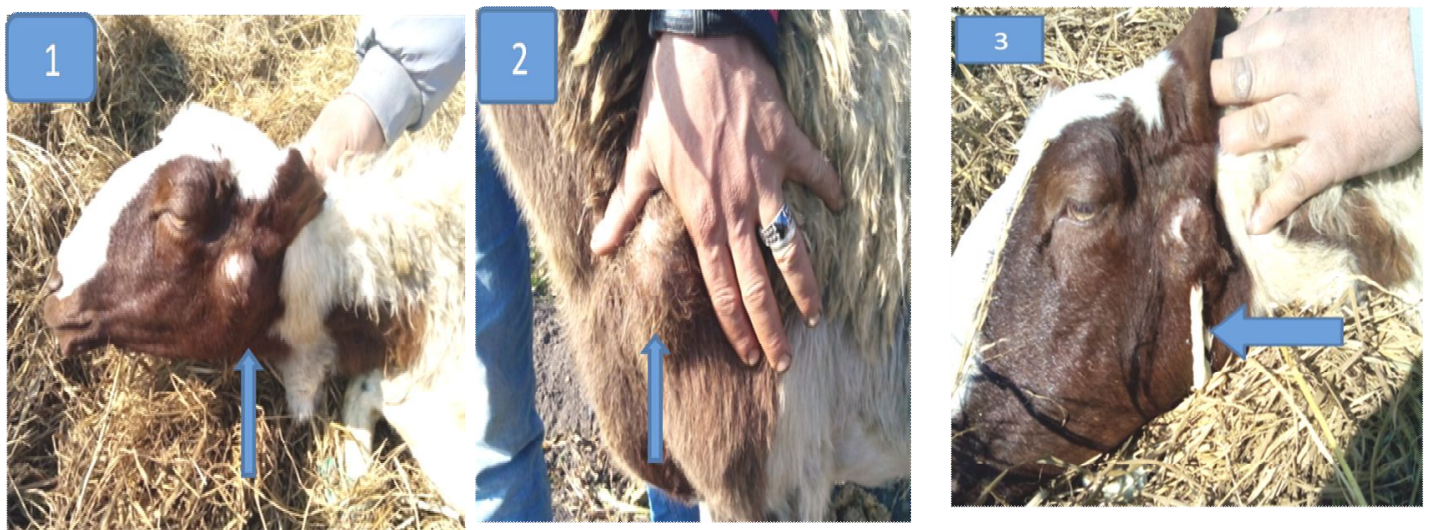

Figure(1): abscess in parotid lymph node, Figure(2): abscess in prescapular lymph node. Figure(3) open abscess creamy pus.

Table (4): Direct detection of C. pseudotuberculosis in needle biopsy samples of CLA-affected and apparently normal animals using the mPCR assay.

\begin{tabular}{|l|c|c|c|c|c|}
\hline \multirow{2}{*}{\begin{tabular}{c}
\multirow{2}{*}{$\begin{array}{c}\text { Herd } \\
\text { Status }\end{array}$} \\
\multirow{2}{*}{ No of samples }
\end{tabular}} & \multicolumn{2}{c|}{ rpoB } & \multicolumn{2}{c|}{ PLD } \\
\cline { 3 - 6 } & & + ve & \% & + ve & \% \\
\hline Infected & 26 & 26 & $100 \%$ & 16 & $\mathbf{6 1 . 5 3 . \%}$ \\
\hline Incontact & 7 & 7 & $100 \%$ & 2 & $\mathbf{2 8 . 5 \%}$ \\
\hline Free & 4 & 4 & $100 \%$ & - -ve & $\mathbf{0 \%}$ \\
\hline Total & 37 & 37 & $100 \%$ & 18 & $\mathbf{4 8 . 6 4 \%}$ \\
\hline
\end{tabular}

mPCR assay result for both genes rpoB (Figures 4 and 5)and PLD (Figures 6 and 7)
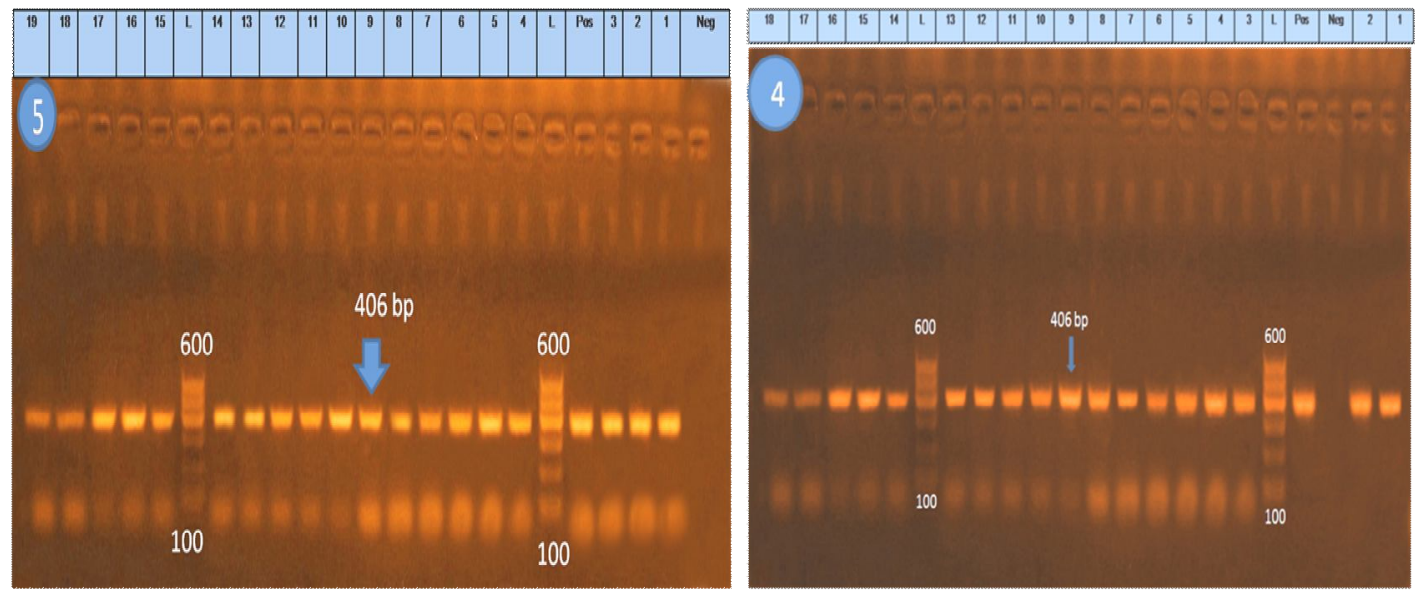

Figures 4 and 5: Positive samples at band size of 406 bp fragment 

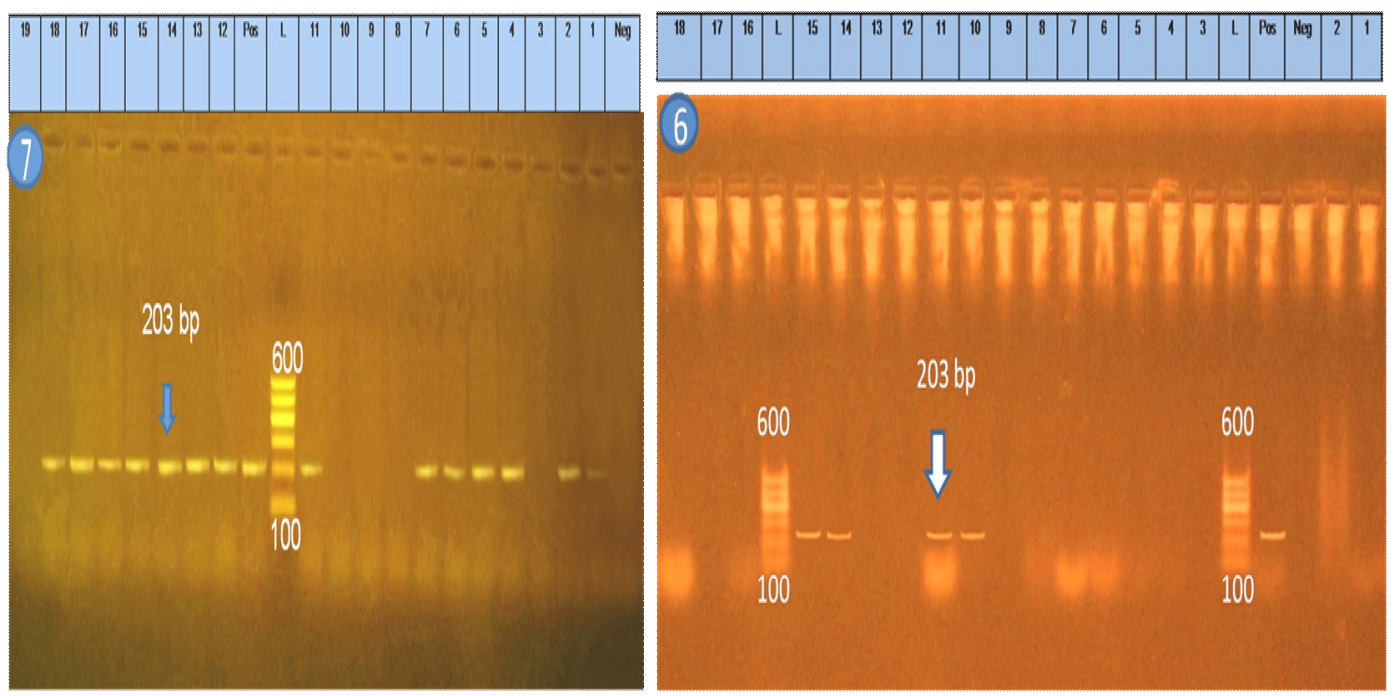

Figure 6 and 7: positive samples at band size of 203 bp fragment

\section{DISCUSSION}

Caseous lymphadenits is a chronic contagious disease of sheep and goats all over the world, characterized by formation of abscesses in superficially located lymph nodes and may affect internal organs and visceral lymph nodes (Baird and Fontaine, 2007; Paule et al., 2004). The disease is endemic in Egypt (Al-Gaabary et al., 2010; Oreiby et al., 2014; Oreiby, 2015).

Regarding to clinical examination, 1257 sheep were clinically examined, from which 37 sheep were randomly selected (26 clinically diseased, 7 incontact and 4 free sheep).The clinical signs appeared on diseased sheep were abscessiation of superficial lymph nodes and in some cases wool was lost over the lesion. These results were in conformity with(Binns et al., 2007) and (Radostitis et al., 2007), who mentioned that the signs of CLA are prominent enlargement of superficial lymph nodes such as submandibular, prescapular, prefemoral, supramammary,popliteal, or in visceral organs such as lungs.
The PCR assay was rapid, specific and as significant as bacterial culture in detecting bacteria directly in the clinical samples. The PCR assay developed in the study can be applied for the diagnosis and control of CLA. Furthermore, the assay can also be applied to detect C. pseudotuberculosis in various clinical samples. (Kumar et al., 2013).

Regarding to PCR examination,37 needle biopsy samples were examined for PCR assay, 37 (100\%) were positive rpoB indicated at $406 \mathrm{bp}$ and this in harmony with (Sammra et al., 2014), who use the rpoB gene Primer to diagnose Arcanobacterium phocisimile and said that $r p o B$ gene is non specific gene encodes the $\beta$ subunit of bacterial RNA polymerase, while $18(48.64 \%)$ were positive PLD results is indicated at $203 \mathrm{bp}$ from which 16 infected sheep and 2 incontact sheep but not detected in free sheep and this agree with (Ilhan, 2013) who used PCR assay protocol for the direct detection of $C$. pseudotuberculosis in 147 samples of lymph nodes (prescapular and mediastinal) from carcasses of naturally infected sheep and to 
compare its performance with the traditional bacteriological culture technique. $C$. pseudotuberculosis was isolated in 81 samples mainly from prescapular nodes and a specific 203 bp PCR amplified PLD gene ,DNA fragment was detected in 85 samples.

Our result revelead that 2 samples were positive come from apparently normal lymph node from apparently normal animal and the explanation is due to contact with affected animal during close confinement or, indirectly, via contaminated shearing equipment (Baird and Fontaine, 2007).

\section{REFERENCES}

Al-Gaabary, M.H., Osman, S.A., Ahmed, M.S and Oreiby, A.F., 2010: Abattoir survey on caseous lymphadenitis in sheep and goats in Tanta, Egypt. Small Ruminant Research 94, 117-124.

Baird, G.J and Fontaine, M.C., 2007: Corynebacterium pseudotuberculosis and its role in ovine caseous lymphadenitis. Journal of Comparative Pathology 137, 179-210.

Binns, S.H., Green, L.E and Bailey, M., 2007: Development and validation of an ELISA to detect antibodies to Corynebacterium pseudotuberculosis in ovine sera. Veterinary microbiology $123,169-179$..

Çetinkaya, B., Karahan, M., Atil, E., Kalin, R., De Baere, $T$ and Vaneechoutte, M., 2002: Identification of Corynebacterium pseudotuberculosis isolates from sheep and goats by PCR. Veterinary microbiology $88,75-83$.
Dorella, F.A., Pacheco, L.G., Oliveira, S.C., Miyoshi, A and Azevedo, V., 2006. Corynebacterium pseudotuberculosis: microbiology, biochemical properties, pathogenesis and molecular studies of virulence. Veterinary research 37,201 218.

Droppa-Almeida, D., Vivas, W.L., Silva K.K., Rezende, A.F., Simionatto, S., Meyer, R., Lima-Verde, I.B., Delagostin, O., Borsuk, $\mathrm{S}$ and Padilha, F.F., 2016. Recombinant CP40 from Corynebacterium pseudotuberculosis. confers protection in mice after challenge with a virulent strain. Vaccine 34, 10.-

Ilhan, Z., 2013: Detection of Corynebacterium pseudotuberculosis from sheep lymph nodes by PCR. Revue de Medecine Veterinaire 164, 60-66..

Kumar, J., Tripathi, B.N., Kumar, R., Sonawane, G.G and Dixit, S.K., 2013: Rapid detection of Corynebacterium pseudotuberculosis in clinical samples from sheep. Tropical animal health and production 45, 1429-1435..

O'Reilly, K., Green, L., Malone, F., Medley, G., Mellor, D and Russell, A. 2006: Parameter estimation of a mathematical model of caseous lymphadenitis transmission in sheep. In: Society for Veterinary Epidemiology and Preventive Medicine. Proceedings of a meeting held at Exeter, UK, 29-31 March 2006., 107-118.

Oreiby, A., Hegazy, Y., Osman, S., Ghanem, $Y$ and Al-Gaabary, M., 2014.: Caseous lymphadenitis in small 
ruminants in Egypt. Tierärztliche Praxis Großtiere 42, 271-277..

Oreiby, A.F., 2015: Diagnosis of caseous lymphadenitis in sheep and goat. Small Ruminant Research 123, 160-166..

Pacheco, L.G., Pena, R.R., Castro, T.L., Dorella, F.A., Bahia, R.C., Carminati, R., Frota, M.N., Oliveira, S.C., Meyer, R., Alves, F.S., Miyoshi, A and Azevedo, V., 2007: Multiplex PCR assay for identification of Corynebacterium pseudotuberculosis from pure cultures and for rapid detection of this pathogen in clinical samples. Journal of medical microbiology 56, 480-486. .

Paule, B., Meyer, R., Moura-Costa, L., Bahia, R., Carminati, R., Regis, L., Vale, V., Freire, S., Nascimento, I and Schaer, R., 2004: Three-phase partitioning as an efficient method for extraction/concentration of immunoreactive excreted-secreted proteins of Corynebacterium pseudotuberculosis. Protein expression and purification 34, 311-316..

Radostitis, O., Gay, C., HinchcliffK, W and Constable, P., 2007: Veterinary medicine: A textbook of the diseases of cattle, horses, sheep, pigs and goats.(10thedn). London, Saunders Co. pp 573..

Sambrook, J., Fritsch, E.Fand Maniatis, T., 1989. Molecular cloning, Vol 2. Cold spring harbor laboratory press New York..

Sammra, O., Balbutskaya, A., Hijazin, M., Nagib, S., Alber, J., Lämmler, C., Abdulmawjood, A., PrengerBerninghoff, E., Timke, $M$ and Kostrzewa, M., 2014: Further Studies on Arcanobacterium phocisimile: a Novel Species of Genus Arcanobacterium. Journal of veterinary medicine 2014, , Article ID 923592, 5 pages.

Severini, M., Ranucci, D., Miraglia, D and Cenci Goga, B., 2003: Pseudotuberculosis in sheep as a concern of veterinary public health. Veterinary research communications 27, 315-318.

Williamson, L.H. (2001): Caseous lymphadenitis in small ruminants Veterinary Clinics of North America Food Animal Practice, 17, 359-371.

Zajdela, A., Zillhardt, P and Voillemot, N., 1987: Cytological diagnosis by fine needle sampling without aspiration. Cancer 59, 1201-1205. 


\title{
الملخص العربي \\ استخلام تقاعل البلمرة المتسلسل في تشخيص مرض السل الكاذب في الاغنام المصابة و المخالطة في محافظة الدقهلية بمصر مرقية
}

\author{
احمد سليم"، سمر عطوة ، عطية الجداوي" ، عماد يونس" \\ * قسم امراض الباطنة والمعدية والاسماك ـكلية الطب البيطري - جامعة المنصورة \\ ** قسم بحوث البكتريولوجي ـمعهد بحوث صحة الحيوان بالدقي
}

الهرف من هذا البحث هو تثخيص مرض السل الكاذب في الاغنام في الحيوانات المصابة والحيوانات المخالطة لهاوالتي لم يظهر عليها اعراض باستخدام تفاعل البلمرة المتسلسل .

تمت هذه الداسة علي I I V حيوان من قطعان مختلفة في محافظة الدقهلية تم فحصهم في الفترة من يناير

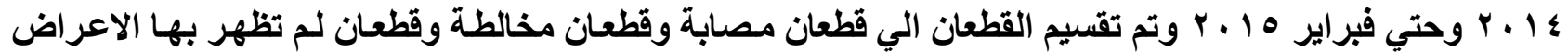

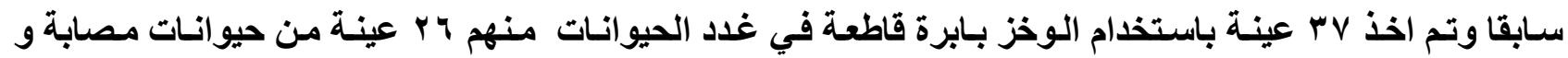
Vعينات من حيوانـات مخالطة و ع عينـات من حيوانـات من قطعان لم تظهر بها الاعراض باستخدام تفاعل البلمرة

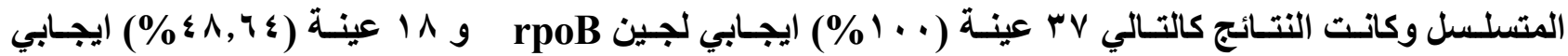
لمكيروب الكورينيبكتريم سيدوتيوبركولوزيس منهم 17 عينة من حيوانات مصابة وفقط حالتان من حيوانات مخالطة . 